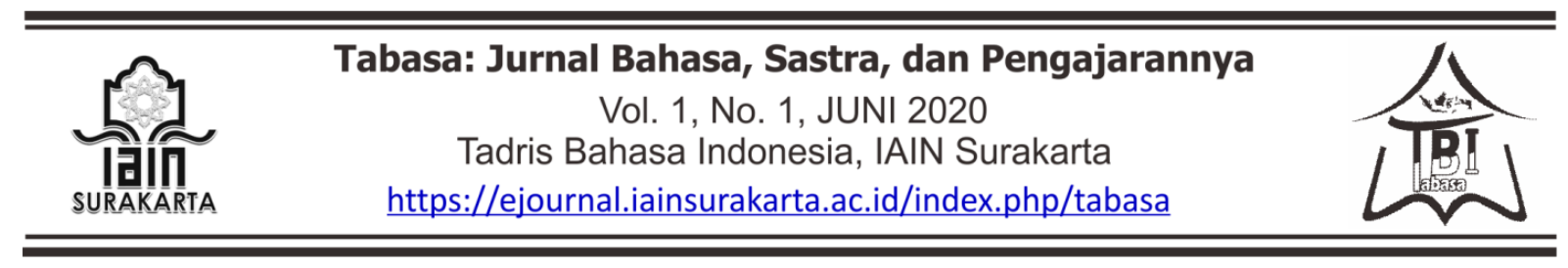

\title{
ANALISIS NILAI-NILAI PENDIDIKAN KARAKTER \\ DALAM NOVEL RUMAH TANPA JENDELA KARYA ASMA NADIA
}

\author{
Agus Yulianto, lis Nuryati, Afrizal Mufti \\ yuliagusyulianto@gmail.com, iisnuryati93@gmail.com, afrizalmufti1@gmail.com \\ SMK Wikarya Karanganyar \\ SMP IT Insan Kamil Karanganyar \\ IAIN Surakarta
}

*) Diterima 15 Juli 2020, disetujui 06 Agustus 2020

\begin{abstract}
Character education is the most important asset in human life to shape the character of students. Character values in a novel's literary work can be used to shape the character of students. This study aims to analyze the values of character education in the novel Rumah Tanpa Jendela by Asma Nadia. This research is a qualitative research using descriptive analysis method. Data analysis techniques are carried out through data interpretation, reading the entire data, analyzing in more detail, applying the coding process to be described, restating in the narrative, and interpreting or interpreting data. The results of this study are the values of character education contained in the novel "House without Window" by Asma Nadia, namely religious, hard work, fond of reading, friendly, and responsible.

Keywords: Values, Character Education, Novel.
\end{abstract}

\begin{abstract}
Abstrak
Pendidikan karakter merupakan aset terpenting dalam kehidupan manusia untuk membentuk karakter peserta didik. Nilai-nilai karakter dalam karya sastra sebuah novel dapat digunakan untuk membentuk karakter peserta didik. Penelitian ini bertujuan untuk menganalisis nilai-nilai pendidikan karakter dalam novel Rumah Tanpa Jendela karya Asma Nadia. Penelitian ini merupakan penelitian kualitatif menggunakan metode analisis deskriptif. Teknik analisis data dilakukan melalui interpretasi data, membaca keseluruhan data, menganalisis lebih detail, menerapkan proses koding untuk dideskripsikan, menyajikan kembali dalam narasi, dan menginterpretasikan atau memaknai data. Hasil dari penelitian ini adalah nilai-nilai pendidikan karakter yang terkandung dalam novel "Rumah Tanpa Jendela" karya Asma Nadia yaitu religius, kerja keras, gemar membaca, bersahabat, dan tanggung jawab.

Kata Kunci : Nilai, Pendidikan Karakter, Novel.
\end{abstract}

\section{PENDAHULUAN}

Akhir-akhir ini, peran lembaga pendidikan banyak disorot oleh masyarakat. Terjadinya kasus tawuran antar pelajar, perilaku asusila, penyalahgunaan narkoba, kekerasan siswa terhadap orang tua dan guru, dan berbagai kasus lain yang melibatkan siswa dianggap sebagai indikator lemahnya peran pendidikan dalam membentuk karakter siswa. Tugas membentuk karakter yang dilakukan oleh lembaga pendidikan pada kenyataannya berbenturan dengan realita kehidupan saat ini. Mudahnya akses terhadap internet yang berarti juga mudah mengakses sisi positif dan negatifnya merupakan tantangan terberat bagi lembaga pendidikan. Kebelummatangan dari segi usia dan emosi ini menjadikan siswa mudah terpikat 
pada lingkar pergaulan yang salah. Kondisi ini memicu jatuhnya nilai-nilai pendidikan karakter yang ditanamkan kepada peserta didik.

Lubis (2008: 18) menyatakan bahwa nilai ialah sebuah hal yang menjadi bagian dalam hidup manusia. la menjadi sebuah poin fundamental dalam hidup seseorang. Setiap tindak-tanduk manusia adalah bagian perwujudan dari nilai itu sendiri.

Pendidikan adalah kebutuhan manusia sejak lahir agar bisa menjalani kehidupan. Pendidikan harus diusahakan, karena pendidikan tidak datang dengan sendirinya. Hal ini sejalan dengan pendapat (Zuriah, 2008: 26) yang menyatakan the definition of education is a conscious and planned effort to realize learning activities and learning processes so that students can develop the potential to gain spiritual spiritual strength, self-control, personality, intelligence, noble character, and the skills needed for himself and the community.

Sedangkan untuk karakter, secara etimologis berasal dari bahasa Latin yaitu karakter, tabiat, watak, yang terdapat pada kelompok seseorang. Karakter terkait dengan keilahian, sesama manusia, lingkungan, negara bangsa, dimanifestasikan dalam pikiran, sikap, hukum, etika, budaya, dan adat istiadat (Fitri, 2012: 20-21). Samani (2011: 41-42) menyatakan bahwa karakter adalah upaya dan perilaku khusus setiap individu untuk bertahan hidup dan bekerja sama, baik dalam keluarga maupun masyarakat. Karakter dapat diartikan sebagai nilai-nilai reaksi individu yang terkait dengan Allah SWT, diri pribadi, antara individu, lingkungan, dan bangsa yang dimanifestasikan dalam pikiran, perilaku, perasaan, kata-kata, dan tindakan berdasarkan ketentuan agama, hukum , sopan santun, budaya, adat istiadat dan estetika. Dari pernyataan tersebut dapat disimpulkan bahwa karakter adalah sikap yang dilihat pada setiap individu dalam hidup bermasyarakat. Pendidikan karakter adalah bagian tak terpisahkan dalam dunia pendidikan. Pemerintah telah mencanangkan Pendidikan Karakter di sekolah yang dituangkan dalam Perpres No 87 Tahun 2017 perihal Penguatan Pendidikan Karakter (PPK) dan selanjutnya dijabarkan dalam Permendikbud No 20 tahun 2018. Pendidikan karakter adalah bagian dari upaya menanamkan karakter-karakter tertentu serta benih kepada siswa untuk dapat menumbuhkan karakter khas mereka dalam kehidupan mereka (Syafaruddin, 2012: 181). Untuk tujuan lain, siswa tidak hanya terbatas pada pemahaman pendidikan sebagai nilai tetapi sebagai bentuk pengetahuan. Selain itu, siswa juga harus menjadikan karakter ini sebagai bagian dari perilaku dalam kehidupan dan secara sadar hidup berdasarkan nilai-nilai ini.

Ada beberapa nilai dalam pendidikan karakter yang dikemukakan oleh para ahli. Di antara mereka, Zubaedi (2011: 74) menyebutkan delapan belas nilai pendidikan karakter sebagaimana tercantum dalam tabel berikut.

\begin{tabular}{|l|l|l|l|}
\hline \multicolumn{4}{|c|}{ Nilai-nilai Pendidikan Karakter } \\
\hline 1 & Religius & 10 & Semangat kerja keras \\
\hline 2 & Jujur & 11 & Cinta tanah air \\
\hline 3 & Toleransi & 12 & Menghargai prestasi \\
\hline 4 & Disiplin & 13 & $\begin{array}{l}\text { Bersahabat atau } \\
\text { komunikatif }\end{array}$ \\
\hline 5 & Kerja keras & 14 & Cinta damai \\
\hline 6 & Kreatif & 15 & Gemar membaca \\
\hline 7 & Mandiri & 16 & Peduli lingkungan \\
\hline 8 & demokratis & 17 & Peduli sosial \\
\hline
\end{tabular}




\begin{tabular}{|l|l|l|l|}
\hline 9 & Rasa ingin tahu & 18 & Tanggung jawab \\
\hline
\end{tabular}

Penanaman nilai-nilai karakter dilakukan dengan menggunakan beragam media, salah satunya melalui karya sastra. Nurhayati (2012: 1) menjelaskan bahwa manusia menciptakan karya sastra sebagai wujud interpretasi pemikiran kreatif yang ada dalam ruang lingkup imajinasi manusia. Karya sastra kreatif lahir dari sebuah seni bahasa dan diibaratkan sebagai sebuah deskripsi kehidupan sosiokultural manusia. Karya sastra dapat menggambarkan kehidupan manusia dalam berbagai bentuk. Adapun nilai-nilai yang dimiliki karya sastra diterima dan dipahami pembaca, yang secara tidak langsung akan memberikan gambaran sikap dan kepribadian pembaca. Sastra tidak sekadar memiliki peran dalam penanaman budi pekerti luhur tetapi juga memiliki peran dalam pembentukan karakter sejak kecil (Rohinah, 2011).

Pendidikan karakter dapat tercermin dalam novel. Nurhayati (2012: 7) mengungkap, novel layaknya fragmen kehidupan panjang manusia. Dalam novel terdapat konflik antartokoh maupun dengan kondisi sosial di sekitarnya. Fakta dan pendapat di atas menjadi dasar penelitian dalam novel Rumah Tanpa Jendela karya Asma Nadia. Novel tersebut sangat kental dengan muatan nilai-nilai pendidikan karakter yang menghidupkan keseluruhan isi novel. Nilai-nilai pendidikan karakter termanifestasi dalam setiap kejadian dan melalui pribadi-pribadi tokoh yang menggambarkan karakter yang baik dalam novel Rumah Tanpa Jendela.

Dalam riset ini, nilai-nilai pendidikan karakter dibatasi pada nilai 1) religius, 2) kerja keras, 3) gemar membaca, 4) bersahabat atau komunikatif, dan 5) tanggung jawab. Lima nilai-nilai pendidikan karakter tersebut dipilih karena memiliki kaitan erat dengan dengan novel yang akan diteliti.

Novel Rumah tanpa Jendela oleh Asma Nadia memiliki latar belakang cerita yang memiliki energi positif bagi para pembaca yang sedang gelisah dalam perbincangan kehidupan ini. Novel tersebut sarat akan nilai-nilai konstruktif dalam hidup, antusiasme dalam berusaha, adalah alasan untuk tidak pernah menyerah dalam memperjuangkan tujuan dan cinta, antusiasme untuk selalu berpikir positif bahwa Tuhan Yang Maha Esa selalu memberikan kemudahan dalam setiap langkah, dan memprioritaskan esensi pentingnya pentingnya optimal pendidikan . Novel ini umumnya penuh dengan nilai-nilai pendidikan. Penelitian ini diharapkan dapat membantu para generasi muda dalam membentuk Dengan penelitian ini penulis berharap agar generasi muda dapat memahami dan menerapkan nilai-nilai pendidikan karakter yang terkandung dalam novel dalam kehidupan sehari-hari.

\section{KAJIAN LITERATUR}

Penelitian tentang pendidikan karakter dalam novel telah dilakukan oleh Susanti (2013) dengan judul Nilai-nilai Pendidikan Karakter dalam novel "Nazarnazar Jiwa". Maksud dari penelitian ini adalah menggambarkan nilai-nilai pendidikan karakter yang terdiri dari: (1) nilai-nilai pendidikan karakter toleransi, (2) nilai-nilai pendidikan karakter kreatif, (3) nilai-nilai pendidikan karakter religius, (4) nilai-nilai pendidikan karakter peduli sosial, (5) nilai-nilai pendidikan karakter jujur, (6) nilai-nilai pendidikan karakter mandiri, (7) nilai-nilai pendidikan karakter rasa ingin tahu, (8) nilai-nilai pendidikan karakter cinta damai, (9) nilai-nilai pendidikan karakter bersahabat/komunikatif, (10) nilai-nilai pendidikan karakter gemar membaca, (11) nilai-nilai pendidikan karakter kerja keras, (12) nilai-nilai pendidikan karakter tanggung jawab. Hasil riset diharapkan dapat dipahami dan dipraktikkan guru dalam proses pembelajaran bahasa dan sastra Indonesia. Unsur instrinsik dan ekstrinsik 
dalam novel merupakan acuan yang diharapkan dapat mengimplementasikan pendidikan karakter serta mendorong siswa untuk bertingkah laku baik.

Penelitian serupa dengan penelitian yang penulis lakukan adalah penelitian oleh Ferbriana (2014) berjudul Nilai-nilai Pendidikan Karakter dalam Novel Rantau Muara Karya Ahmad Fuadi: Tinjauan Sastra Sosiologis. Penelitian ini menggambarkan penerapan nilai-nilai pendidikan karakter dalam novel Rantau Satu Muara bahwa novel ini adalah karya sastra yang sarat dengan konten pendidikan karakter yang sangat berguna untuk meningkatkan kualitas sumber daya manusia di kalangan pendidikan, terutama untuk menghasilkan pendidik dan siswa yang kecerdasan intelektual dan kecerdasan emosi dimanifestasikan dalam perilaku atau perilaku mereka sehari-hari.

Penelitian yang relevan lainnya dilakukan oleh Yufarlina (2018) yang berjudul Pendidikan Karakter Dalam Novel Cinta 2 Kodi Karya Asma Nadia. Penelitian ini memaparkan tentang nilai pendidikan karakter yang dapat diintegrasikan melalui pembelajaran Bahasa Indonesia. Peneliti memaparkan empat belas nilai pendidikan karakter yang terdapat dalam novel tersebut, yaitu relegius, jujur, disiplin, kerja keras, kreatif, cinta tanah air, mandiri, demokrasi, rasa ingin tahu, menghargai prestasi, bersahabat, gemar membaca, peduli sosial, dan tanggung jawab.

\section{METODE PENELITIAN}

Penelitian ini termasuk dalam kategori penelitian kualitatif dengan metode analisis deskriptif. Menurut Bogdan dan Taylor dalam Basrowi (2008: 20), metode penelitian kualitatif adalah prosedur penelitian yang menghasilkan data deskriptif, dalam bentuk kata-kata tertulis atau lisan dari objek dan perilaku yang diamati. Dalam meneliti karya sastra menurut Ratna (2012: 47), data penelitian kualitatif formal diperoleh dari teks-teks novel dalam bentuk kata-kata, kalimat, dan wacana.

Sumber data dalam penelitian ini adalah novel Rumah Tanpa Jendela karya Asma Nadia, cetakan pertama tahun 2017 dengan jumlah halaman 215 oleh Republika Publisher. Data penelitian ini berupa dialog dan paparan cerita yang mengandung nilai-nilai pendidikan karakter. Instrumen utama dalam penelitian ini adalah peneliti itu sendiri. Peneliti mencatat dan menganalisis data selama penelitian untuk mengumpulkan data seperti kutipan yang diperoleh dari teks novel. Kemudian para peneliti sendiri memproses dan menganalisis data secara terperinci. Data dikumpulkan dengan cara berikut. (1) Baca dan pahami konten isi novel berulang kali, (2) cari referensi terkait penelitian. (3) tulis setiap kata atau kalimat yang mengandung nilai-nilai pendidikan yang ditemukan saat membaca novel.

Dalam mengolah data dalam penelitian ini, teknik analisis data dilakukan dengan menginterpretasikan data, membaca seluruh data, menganalisis secara lebih rinci, melakukan proses pengkodean untuk dijelaskan, menceritakan kembali hasil analisis, dan menafsirkan atau menginterpretasikan data.

\section{HASIL DAN PEMBAHASAN}

\section{Nilai-nilai Pendidikan Karakter dalam Novel Rumah Tanpa Jendela karya Asma Nadia yang Berhubungan dengan Religius.}

Hasil penelitian ini adalah nilai-nilai pendidikan karakter yang berhubungan dengan relegius berdasarkan teori pendidikan karakter yang dikemukakan oleh Zubaidi. 
a) Berdoa

Berdoa adalah bentuk ibadah yang dilakukan oleh individu kepada Allah SWT. Dan salah satu cara untuk mengharapkan sesuatu dari Allah, yang terkait dengan kebaikan. Agar nantinya diberi kemudahan dan kehalusan dalam menjalani hidup ini.

Berdoa mendeskripsikan bahwa manusia membutuhkan pertolongan dari Sang Pencipta. Dalam novel Rumah Tanpa Jendela (RTJ) ini kegiatan yang berhubungan dengan berdoa ini diperlihatkan oleh tokoh Rara dalam kutipan berikut.

Matanya berkaca-kaca. Butiran air yang mau tumpah ia tahan sekuat tenaga. Gadis kecil dengan bola mata bulat itu menggigit bibir keraskeras. Berharap dengan begitu, genangan air yang siap menderas akan berhenti. Dia harus kuat, percuma menangis. Dia harus kuat. Lebih baik berdoa. Ibu dulu sering mengulang-ulang nasihat ini padanya. (RTJ:3-4)

Pada kutipan ini kebiasaan berdoa ditunjukkan oleh Rara ketika dalam keadaan bersedih dan menangis. Rara memiliki karakter bedoa ini karena terinspirasi dari nasihat ibunya yang terus diulang-ulang.

\section{b) Berprasangka Baik kepada Allah}

Manusia tidak pernah lepas dari masalah. Ketika satu masalah selesai, akan muncul masalah berikutnya. Pada kondisi seperti ini, sikap yang sangat dibutuhkan adalah berprasangka baik pada Allah. Berbaik sangka pada Allah SWT artinya selalu menyadari bahwa ketetapan Allah SWT adalah ketetapan terbaik.

Berprasangka baik ditunjukkan tidak hanya ketika menghadapi masalah, tetapi juga ketika berdoa yang diwujudkan dengan tetap mengulang doa dengan penuh keyakinan Allah akan mengabulkan. Sikap berprasangka baik kepada Allah dalam berdoa ditunjukkan oleh tokoh ibu Rara dalam kutipan berikut.

"Berdoa, Ra..mengaji. Minta sama Allah."

"Apa Allah selalu mengabulkan doa?"

Dia ingat perempuan yang melahirkannya tersenyum saat mendengar pertanyaan itu.

"Allah mendengar doa, Ra. Allah nggak pernah menyia-nyiakan doa yang meminta." (RTJ:4)

Pada kutipan di atas, ibu Rara meyakinkan Rara agar senantiasa berdoa kepada Allah swt dan berprasangka baik bahwa Allah akan mengabulkan doanya. Ibu Rara menekankan bahwa Allah swt tidak akan menyia-nyiakan doa seorang hamba yang meminta.

\section{c) Rajin Beribadah/ Rajin Salat}

Salah satu parameter keberhasilan dari nilai pendidikan karakter relegius yang kedua adalah tekun menjalankan ibadah, dalam hal ini salat. Salat merupakan kegiatan peribadatan kepada Tuhan Yang Maha Esa. Dengan menjalankan salat akan terbangun hubungan antara manusia dengan Tuhan Yang Maha Esa. Salat adalah salah satu bentuk ibadah yang paling utama dari pegabdian seorang individu kepada Sang Pencipta. 
Dalam novel Rumah Tanpa Jendela (RTJ) tokoh Rara tetap berusaha untuk melakukan salat dan ia merasakan kenikmatan dan anugerah dari Tuhan ketika salat. Hal ini terihat dalam kutipan berikut.

"Sudah Salat Dhuhur?"

Rara kecil mengangguk. Rambutnya bergoyang-goyang. Ibu tidak pernah bosan mengingatkan salat.

Salat itu amal pertama yang ditanyai Allah, Ra.

Salat juga bisa menjadi penolong kita, Ra...kalau kita sedang susah. (RTJ:19)

Pada kutipan di atas, Rara melaksanakan perintah Allah dengan mengerjakan salat atas nasehat dari Ibunya. Dalam nasehat tersebut si lbu menjelaskan bahwa dengan melaksanakan ibadah salat dapat menjadi penolong manusia ketika dalam keadaan susah. Selain itu juga ditegaskan bahwa salat merupakan amal pertama yang akan ditanyakan oleh Allah SWT. kelak di akhirat.

\section{d) Bersyukur}

Syukur adalah ungkapan syukur kepada Allah SWT adalah manifestasi dari sikap menghargai berkah dan hadiah yang Allah berikan kepada umatNya. Syukur melayani semua kesenangan dan karunia Allah untuk tujuan akhir. Salah satu sikap syukur sebagai wujud manifestasi dari kenikmatan rahmat Allah, ditunjukkan dengan mengucapkan kalimat hamdallah. Ini ditunjukkan oleh karakter Rara dalam kutipan berikut:

Rara bersyukur bahwa dia tidak pernah menghentikan doanya. Mungkin selama ini jalannya salah, sampai Nyonya Alia keluar. Mungkin juga bahwa Tuhan telah menunda pemberiannya - termasuk permintaan kesembuhan Simbok - sehingga Rara lebih bersyukur karena bersama neneknya. (RTJ: 183)

Kutipan ini menunjukkan tokoh Rara mensyukuri hidayah yang diberikan kepadanya, yaitu hidayah berupa keistiqomahan dalam berdoa. Rara juga memanjatkan syukur atas kebersamaan yang lebih lama dengan sang nenek.

\section{e) Taat pada Aturan Agama}

Aturan dalam agama dibuat agar terjadi keteraturan dalam hidup di dunia. Aturan tidak untuk mengekang manusia, justru sebaliknya untuk membebaskan manusia dari kesalahan dan keterpurukan hidup. Sikap taat terhadap aturan agama akan menyelamatkan hidup manusia.

Sikap taat pada aturan agama dalam novel Rumah Tanpa Jendela ditunjukkan oleh tokoh Bapak sebagaimana dalam kutipan berikut:

Supaya miskin di dunia tidak memanjang hingga di akhirat kelak. Itu sebabnya dia marah dan tidak bisa menerima kelakuan Asih yang menjual diri hanya agar hidup senang, bisa makan enak, dan membeli ini itu. Atau membiarkan saudara sedarahnya itu mendekati Rara.

Yang haram tak pernah berkah. Dia harus melindungi Rara agar tidak tergiur gaya hidup budenya. (RTJ: 109) 
Sikap Bapak yang tidak menyetujui kelakuan Asih menjual diri agar bisa mendapat uang secara cepat menunjukkan bahwa Bapak taat kepada aturan agama. Bapak lebih pilih hidup miskin dari pada memakan sesuatu yang haram.

\section{Nilai-nilai Pendidikan Karakter dalam Novel Rumah Tanpa Jendela karya Asma Nadia yang berhubungan dengan sikap kerja keras.}

Nilai fungsi dalam pendidikan karakter yang kedua pada novel Rumah Tanpa Jendela adalah sikap kerja keras. Kerja keras merupakan sebuah sikap terpuji yang harus ada dalam diri setiap orang untuk mencapai keberhasilan dalam menjalankan hidup. Sikap kerja keras merupakan kunci untuk menggapai pintu kesuksesan dan cita-cita yang diangan-angankan oleh setiap orang. Oleh karena itu, manusia diharapkan untuk memiliki sikap kerja keras sehingga akan tumbuh dalam dirinya rasa optimis dan berfikiran positif dalam menjalani kehidupan. Ada beberapa paramater dari sikap kerja keras yang di temukan dalam teks novel Rumah Tanpa Jendela.

\section{a) Bersungguh-sungguh}

Sikap sungguh-sungguh dalam kehidupan ini sangat dibutuhkan untuk mencapai sebuah cita-cita. Sikap bersungguh-sungguh merupakan salah satu sikap bekerja dengan giat dan tekun. Dalam mewujudkan sikap serius tidak harus selalu dikaitkan dengan kekuatan fisik. Sikap serius ini juga dapat dilakukan dengan menumbuhkan pemikiran serius dalam melakukan setiap pekerjaan. Melakukan pekerjaan dengan sungguh-sungguh dilakukan untuk mencapai tujuan kesuksesan individu dan pencapaian kepada Allah, baik untuk kepentingan dunia dan akhirat.

Sikap serius dapat digunakan dalam semua tindakan baik mencari pengetahuan, mencari rezeki, dan melaksanakan tugas sesuai dengan profesi masing-masing. Ini seperti yang ditunjukkan oleh karakter Bapak dalam kutipan berikut: Tapi Anda sering pulang terlambat akhirakhir ini. Mereka jarang bicara. Pagi-pagi, sebelum Rara bangun, pria itu sudah pergi. (RTJ: 37)

Sikap Bapak yang selalu berangkat kerja pagi-pagi sekali menunjukkan kesungguhannya sebagai kepala keluarga dalam mencari nafkah untuk keluarga.

\section{b) Pantang Menyerah}

Sikap pantang menyerah merupakan suatu bentuk dalam melakukan sesuatu atau mencapai sebuah keinginan dengan serius. Sikap pantang menyerah merupakan sebuah bentuk usaha individu yang dilakukan sebagai upaya berlandaskan pada sebuah sikap yang berupa kesungguhan, kerja keras, ketekunan dan perjuangan. Ketika ingin mencapai sebuah keinginan atau apa yang dicita-citakan maka orang tidak dapat lepas dari sikap pantang menyerah. Hal ini ditunjukkan oleh tokoh Bapak dalam kutipan sebagai berikut.

Selebihnya sama saja. Bapak masih memulung atau menjual ikan hias di dalam pikulan kayu. Pemandangan langka di Jakarta, sebab tukang ikan hias lain sudah menggunakan gerobak dengan stoples-stoples 
kaca atau beragam kantong plastic yang digantungkan dan berisi ikan. (RTJ:18)

Untuk menghidupi keluarga, Bapak tidak menyerah. Meski tidak memiliki gerobak untuk tampat berjualan ikan hias, Bapak menggunakan pikulan kayu. Sebuah sikap pantang menyerah seorang bapak demi keluarganya.

\section{c) Memiliki Cita-cita}

Setiap individu dalam kehidupan ini memiliki sebuah cita-cita. Segala sesuatu yang akan dan ingin kita capai disebut dengan cita-cita. Mendorong setiap orang untuk meraih apa yang diimpi-impikannya merupakan salah satu bentuk motivasi untuk meraih cita-cita. Maka dari itu, bercita-cita memberikan nilai positif pada diri seseorang khususnya bagi peserta didik. Hal ini terlihat dalam sebuah kutipan:

Semua yang terjadi mengembalikan keyakinan Rara akan doa, juga semangatnya untuk mencatat keinginan, harapan, dan cita-cita yang ingin dicapai. Seperti terus melanjutkan sekolah dan menjadi orang besar.

Mungkin suatu hari, dia ingin punya sekolah sendiri agar anak-anak tak mampu lain bisa belajar gratis, seperti dia dulu. Atau meneruskan semangat Bu Alia dengan memperbanyak rumah baca bagi anak-anak miskin, agar mereka tahu begitu banyak sisi indah dan menakjubkan di dunia. Mungkin jua ... dua-duanya, pikir Rara. (RTJ: 185).

Kutipan di atas menunjukkan sikap Rara yang memiliki cita-cita tinggi, bagaimana pun keadaannya. Dan Rara menuliskan cita-citanya itu dalam sebuah buku catatan. Menuliskan cita-cita itu penting sebagai motivasi bekerja keras untuk mencapainya.

\section{d) Kreatif}

Sikap kreatif merupakan sikap yang ditunjukkan seseorang dengan selalu berusaha mencari-cari sesuatu yang baru baik ide-ide baru maupun hal-hal baru yang terkadang tidak terpikirkan oleh orang lain. Seorang yang kaya dengan kreativitas hidupnya akan selalu berwarna dan bermanfaat, baik bagi dirinya maupun bagi orang lain. Dalam novel Rumah Tanpa Jendela ini sikap kreatif diperlihatkan oleh tokoh Bapak.

Tapi yang terjadi adalah hal berbeda. Jauh dari kesan

kejutan membahagiakan.

Rara terdiam, melongo.

Dia tak menemukan jendela impian. Hanya lukisan jendela yang dibuat Bapak dengan sisa-sisa cat. (RTJ: 73)

Bapak berpikir keras agar bisa memenuhi keinginan Rara memiliki sebuah jendela. Karena belum bisa memenuhi permintaan Rara, Bapak mempunyai ide kreatif membuat "gambar" jendela, meskipun pada akhirnya hal itu malah membuat Rara kecewa. 


\section{Nilai-nilai Pendidikan Karakter dalam Novel Rumah Tanpa Jendela karya Asma Nadia yang berhubungan dengan gemar membaca}

Nilai karakter yang ketiga, yaitu gemar membaca. Karakter gemar membaca merupakan perwujudan pada perilaku yang mencerminkan suatu bentuk kegiatan yang disukai untuk menambah ilmu dengan cara rajin membaca. Dengan semakin tekun membaca maka akan menambah pengetahuan dan wawasan seorang individu. Sikap dari gemar membaca ini harus ditanamkan dalam diri peserta didik dan dalam diri kita semua sehingga akan meningkatkan kapasitas keilmuan dan wawasan. Ada beberapa indikator yang ditemukan dalam teks novel Rumah Tanpa Jendela.

\section{a) Cinta IImu}

Salah satu karakter yang harus ada dalam diri orang yang ingin menuntut ilmu adalah cinta ilmu. Segala sesuatu jika didorong oleh rasa cinta maka akan terasa menyenangkan. Hal ini terlihat dalam perilaku sang tokoh Rara dan teman-temannya.

Anak-anak di kampung Rara sekarang punya sekolah. Tidak harus iri tiap kali melihat sekolahan Obama. Walau sederhana, mereka bisa belajar setiap hari. Ada buku tulis, pensil, buku cerita, kertas gambar, bahkan crayon yang sering menjadi rebutan anak-anak saat Bu Alia meminta mereka menggambar.

Gadis kecil itu senang belajar. Dia juga suka membaca, seperti ia gemar menggambar. Apalagi aka nada yang memberi nilai di kertas gambarnya. (RTJ: 52-53)

Keserdahanaan dan kemiskinan tak menghalangi tokoh Rara dan teman-temannya menuntut ilmu. Dengan sarana seadanya, mereka tetap belajar dengan ceria dan sungguh-sungguh.

\section{b) Suka Membaca}

Manusia merupakan makhluk yang serba terbatas, baik dari segi waktu maupun tempat. Keterbatasan itu membatasi usaha manusia untuk mengumpulkan pengetahuan yang tersebar di muka bumi ini. Membaca merupakan salah satu jalan yang bisa ditempuh untuk mengurai keterbatasan tersebut. Dengan membaca, manusia dapat memperroleh pengetahuan luas atau mengunjungi tempat-tempat yang jauh sekalipun. Membaca adalah jendela dunia. Dengan membaca, dunia akan terbuka.

Kebiasaan suka membaca ditunjukkan oleh tokoh lbu. Hal ini ditunjukkan dalam paragraph berikut:

Kalimat Ibu itu baru belakangan ia pahami. Ah, Ibu memang cerdas.

Tidak seperti kebanyakan ibu teman-temannya yang suka ngumpul dan ngobrol tidak karuan, ibunya suka membaca. Jika Bapak pulang memulung, Ibu akian memilah hasil pencarian hari itu, dan memisahkan majalah atau koran-koran bekas. Membacanya sebelum dijual lagi. (RTJ:11)

Meskipun tinggal di perkampungan kumuh, tetapi tokoh lbu suka membaca. Dengan keterbatasannya, tokoh lbu tidak mau ketinggalan informasi dengan cara membaca koran bekas hasil memulung suaminya. Ini menunjukkan semangat sang lbu yang sangat tingi dalam mencari pengetahuan. 


\section{c. Semangat Belajar}

IImu merupakan hartu karun yang tak ternilai harganya. Tak semua berkesempatan dan berkemauan untuk menggalinya. Ada kesempatan, tak ada kemauan. Ada kemauan, tak ada kesempatan. Hanya orang-orang yang memiliki semangat belajar yang tinggi bisa menaklukkan keduanya.

Pada novel Rumah Tanpa Jendela ini, tokoh Rara memiliki semangat belajar itu. Kemauan belajarnya tinggi, maka ketika kesempatan datang dengan segera dia menyambutnya. Dia tak memedulikan meski usianya sudah terhitung terlambat untuk mulai belajar dari awal.

Seperti mendapatkan anugerah akan mimpi yang tak pernah dicatatnya, hari itu Rara mulai sekolah. Memang agak telat karena usianya sudah hamper Sembilan tahun. Tapi tak apa. (RTJ: 52)

\section{Nilai-nilai Pendidikan Karakter dalam Novel Rumah Tanpa Jendela karya Asma Nadia yang Berhubungan dengan Bersahabat atau Komunikatif}

Bersahabat atau komunikatif sebagai bagian dari karakter utama mendorong terjadinya hubungan yang menyenangkan antara satu orang dengan orang lain. Sikap bersahabat membuat seseorang mudah diterima oleh orang lain, sedangkan komunikatif membuat seseorang mudah dipahami. Dengan dua sikap yang saling berkaitan ini, akan terrcipta kerja sama yang harmonis.

\section{a. Senang bergaul dengan Orang Lain}

Karakter bersahabat salah satunya ditunjukkan dengan tindakan senang bergaul dengan orang lain. Orang yang bersahabat tidak membedabedakan dengan siapa bergaul. Dia bisa masuk ke berbagai kalangan meskipun sangat berbeda jauh dengan kalangannya sendiri.

Sikap senang bergaul dengan orang lain ditunjukkan oleh tokoh Alia. Meskipun berasal dari keluarga berkecukupan, tapi tidak canggung bergaul dengan anak-anak tidak mampu.

"Sudah jelas atau ada yang ingin bertanya?"

"Bu!" suara Akbar tiba-tiba, lantang sekali.

"Ya?"

"Ibu sudah punya pacar?"

Pertanyaan yang menghasilkan belasan gumpalan kertas dilemparkan anak-anak kea rah Akbar disertai teriakan 'Huuu ...' yang panjang.

Rara sempat khawatir pertanyaan Akbar akan mengakibatkan ibu guru mereka mengurungkan niat mengajar. Syukurlah, ternyata Bu Alia hanya tersenyum. (RTJ: 50$)$

Dari kutipan ini terlihat kalau Alia mudah bergaul dengan anak-anak tidak mampu yang secara usia maupun kondisi ekonomi jauh berbeda. la tidak marah meskipun anak-anak usil menanyainya tentang pacar. Perilaku ini merupakan bukti bahwa tokoh Alia senang bergaul dengan orang lain meski dengan latar belakang yang jauh berbeda.

\section{b. Rendah Hati}

Kerendahan hati adalah bagian dari karakter yang ramah. Persahabatan berdasarkan kerendahan hati dan tidak memandang rendah 
orang lain membuat persahabatan yang langgeng. Sebaliknya, sikap sombong kepada orang lain akan merusak persahabatan. Dalam novel Rumah Tanpa Jendela, sikap rendah hati dan tidak sombong ini ditunjukkan oleh tokoh Rara seperti dalam kutipan berikut:

Akbar dan Rafi sempat cemburu, menganggap Rara tidak akan peduli lagi pada mereka setelah punya teman bermobil. Syukurnya, perasaan itu disingkirkan jauh-jauh setelah menyaksikan sikap Rara yang tidak berubah. Masih menyapa dan mau bermain, tidak lantas jadi sombong. (RTJ: 61)

Kadang perubahan nasib membuat orang menjadi sombong dan lupa pada teman lama. Akan tetapi, Rara tidak menunjukkan sikap seperti itu. Dalam kutipan di atas, Rara tetap mau bergaul dengan teman lama dan tidak menjadi sombong karena telah berteman dengan anak orang kaya.

\section{c. Menghargai Kekurangan}

Tidak ada yang sempurna di dunia ini. Setiap sesuatu selalu ada sisi lebih dan kurangnya. Kelebihan dan kekurangan pada masing-masing orang menciptakan perbedaan. Sikap bersahabat tidak akan memandang seseorang hanya dari kelebihannya saja, melainkan juga kekurangannya.

Sikap ini dipraktikkan oleh Rara saat berteman dengan Aldo, seorang anak autis maupun dengan Rafi yang gagap dalam berbicara.

"Tapi kalian harus janji!"

Mereka menunggu kelanjutan kalimat gadis kecil itu dengan heran. Kok bertemu saja pakai persyaratan.

"Janji ap ...app...ap..."

"Api, apel ..."

"Apusan!"

Gelak tawa terdengar. Rara buru-buru meneruskan.

"Janji nggak boleh seperti yang barusan." (RTJ:61)

\section{d. Kasih Sayang}

Sejak lahir, manusia membutuhkan kasih sayang. Dengan kasih sayang, hidup akan penuh kedamaian dan ketenteraman. Kasih sayang melembutkan hati dan memberikan energi positif. Kasih sayang diperlukan tidak hanya dalam keluarga, tetapi juga dalam hubungan persahabatan. Dalam kutipan novel ini, ditunjukkan sikap kasih sayang Aldo kepada Rara.

"Kasihan ... Ra...Rara, ya... Nekk!"

Grandma nodded. Stroking his granddaughter's wavy black hair. Conveying sad news has never been easier. How could Rara be able to receive this bitter news? (RTJ: 118).

Aldo sebagai penyandang autis sangat menyayangi Rara, teman barunya. Kasih sayangnya dibuktikan dengan menemani Rara melewati masa sulit karena kehilangan Bapaknya.

\section{Nilai-nilai Pendidikan Karakter dalam Novel Rumah Tanpa Jendela karya Asma Nadia yang Berhubungan dengan Tanggung Jawab}


Nilai pendidikan karakter kelima yaitu tanggung jawab. Tanggung jawab menuntut seseorang untuk menanggung segala sesuatu. Orang yang bertanggungjawab berarti sadar akan tugas dan kewajiban yang harus diemban. Dia berani mengambil keputusan dan siap menanggung segala akibatnya. Tanggung jawab dapat diwujudkan dalam bentuk pengabdian secara totalitas kepada tugas dan pengorbanan yang tulus dalam menuntaskan tugas. Seseorang memiliki tanggung jawab terhadap dirinya sendiri, keluarga, masyarakat, negara, dan Tuhan.

Pada novel Rumah Tanpa Jendela ini, terdapat nilai pendidikan karakter tanggung terhadap diri sendiri, terhadap keluarga, dan terhadap masyarakat.

\section{a. Tanggung Jawab terhadap Diri Sendiri}

Sikap tanggung jawab terhadap diri sendiri menuntut seseorang untuk memenuhi kewajiban dirinya dengan sebaik-baiknya. Pemenuhan kewajiban terhadap diri sendiri akan menumbuhkan sikap tanggung jawab yang lebih besar. Seseorang tidak akan dapat mengambil tanggung jawab untuk orang lain jika tanggung jawab untuk dirinya sendiri diabaikan.

Sikap bertanggung jawab terhadap diri sendiri ditunjukkan oleh tokoh Adam.

"Bukannya anak band itu identik dengan minuman keras dan drugs?"

Upps. Pertanyaan itu!

Alia kontan menutup bibi. Mereka memang mulai akrab, tetapi bagaimanapun usia pertemanan yang terjalin masih seumur jagung.

Tetapi lelaki yang suka mengenakan jaket kulit itu tidak tersinggung. Santai saja saat memberikan jawaban, Drugs? Nggak lah. Ngerokok aja aku nggak, kok!" (RTJ)

Kondisi keluarga Adam yang agak kacau sangat memungkinkan bagi Adam untuk melarikan diri ke obat-obatan terlarang. Akan tetapi Adam tidak melakukannya. Menjaga tubuh agar tetap sehat dengan tidak meracuninya dengan obat-obatan terlarang merupakan suatu bentuk sikap bertanggungjawab terhadap diri sendiri.

\section{b. Tanggung Jawab terhadap Keluarga}

Keluarga merupakan satuan masyarakat terkecil yang biasanya terdiri dari ayah, ibu, dan anak. Seluruh anggota keluarga bertanggungjawab atas keberlangsungan hidup keluarga yang mencakup kesejahteraan, keselamatan, dan perlindungan.

Sikap bertanggungjawab terhadap keluarga ditunjukkan oleh tokoh Adam. Adam memiliki seorang adik yang bernama Aldo yang menyandang autis. Anggota keluarga lain tidak bisa menerima kehadiran Aldo, termasuk kedua orang tuanya. Maka Adam sebagai kakak mengambil alih tanggung jawab ini. Kutipan paragraf berikut menunjukkan karakter tersebut:

Adam lebih rajin menghabiskan waktu dengan Aldo. Anak muda itu bahkan membuang keinganan merokok jauh-jauh, hanya karena tidak ingin menambah maslaah kesehatan adiknya. Penuh kasih, dia mengajak si bungsu ke kamar untuk mendengarkan music. Adam bahkan merekan gitar yang sebelumnya tidak pernah disentuh oleh siapapun, untuk dimainkan tangan kecil Aldo. (RTJ: 130) 


\section{c. Tanggung Jawab terhadap Masyarakat}

Manusia tidak bisa melepaskan diri dari tanggungjawabnya sebagai bagian dari anggota masyarakat. Dengan segala kekurangannya, manusia membutuhkan bantuan manusia orang lain. Sikap seenaknya sendiri akan mengacaukan tata laksana kemasyarakatan. Karena itu, sikap tanggung jawab harus dikembangkan untuk memastikan keberlangsungan kehidupan di masyarakat yang harmonis.

Tokoh Alia dalam novel Rumah tanpa Jendela dengan apik menunjukkan perilaku tersebut. Kepeduliannya kepada pendidikan anak-anak di perkampungan kumuh merupakan contoh nyata tanggung jawab seseorang terhadap masyarakat. Hal ini ditunjukkan dalam kutipan berikut:

Jika diizinkan, dia ingin membuka sekolah singgah, sekaligus taman baca bagi anak-anak di sana. Barangkali bisa menjadi alternative, selain satusatunya madrasah yang terletak cukup jauh dan memerlukan biaya.

Awalnya ada yang mencurigai niat baik gadis itu,. Bahkan mengira Alia disponsori kelompok atau partai tertentu. Allah.

Tapi Alia terus meyakinkan, tidak ada siapa-siapa di belakangnya kecuali

"Gratis? Tidak mbayar?" Tanya seorang ibu dengan nada galak, tidak percaya.

Alia mengangguk. Tidak ada biaya apa pun. (RTJ: 27)

\section{KESIMPULAN}

Berdasarkan temuan dalam studi dan diskusi tentang nilai-nilai pendidikan karakter dalam novel Rumah Tanpa Jendela oleh Asma Nadia, dapat disimpulkan sebagai berikut: Nilai-nilai pendidikan karakter agama ditunjukkan oleh indikator dalam bentuk doa yang rajin berdoa, beribadah. Saya berdoa dengan tekun, percaya, bersyukur, dan mematuhi aturan agama. Nilai-nilai pendidikan karakter kerja keras ditunjukkan melalui indikator sikap tulus, tidak pernah menyerah, memiliki cita-cita, dan menjadi kreatif. Nilai-nilai pendidikan karakter seperti membaca dibuktikan oleh indikator-indikator cinta sains, cinta membaca, dan antusiasme belajar. Nilai-nilai pendidikan karakter bersahabat/komunikasi nampak melalui indikator karakter senang bergaul dengan orang lain, rendah hati, menghargai kekurangan dan kasih sayang. Nilai-nilai pendidikan karakter tanggung jawab termuat melalui indikator nilai-nilai yang menganjurkan kepada karakter tanggung jawab pada diri sendiri, keluarga, dan masyarakat.

Berdasarkan kesimpulan ini, maka novel Rumah Tanpa Jendela ini sangat direkomendasikan sebagai bahan ajar karena di dalamnya memuat nilai-nilai pendidikan karakter utama. Hal ini sangat sesuai dengan program pemerintah saat ini, yaitu Penguatan Pendidikan Karakter (PPK). Program ini dimaksudkan untuk menyiapkan peserta didik tidak hanya dengan intelektual yang tinggi tapi juga dengan karakter yang mulia.

\section{SARAN}

Berdasar kesimpulan di atas, maka saran bagi siswa adalah hendaknya dapat mengambil manfaat dari novel ini, memahami isinya dan menerapkan karkater positif yang terdapat dalam cerita. Adapun bagi guru, novel ini disarankan untuk dimasukkan dalam bahan ajar pembelajaran sastra di kelas dengan memperhatikan 
bagaimana pendidikan karkater bisa disampaikan melalui sebuah karya sastra. Bagi peneliti lain, disarankan melakukan penelitian yang lebih mendalam terhadap karya sastra dan menyebarluaskan kepada masyarakat sehingga nilai-nilai kebaikannya dapat dinikmati oleh lebih banyak pembaca.

\section{DAFTAR PUSTAKA}

Basrowi, S. (2008). Memahami Penelitian Kualitatif. Jakarta: Rineka Cipta.

Ferbriana, Noni., Thahar, H.E., E. (2014). Nilai-Nilai Pendidikan Karakter Dalam Novel Rantau Satu Muara Karya Ahmad Fuadi: Tinjauan Sosiologi Sastra. Jurnal Bahasa, Sastra Dan Pembelajaran, 2(3).

Fitri, Z. A. (2012). Pendidikan karakter Berbasis Nilai dan Etika Sekolah. Yogyakarta: Ar-Ruzz Media.

Mawardi, L. (2008). Evaluasi Nilai Pendidikan. Yogyakarta: Pustaka Pelajar.

Nadia, A. (2017). Rumah Tanpa Jendela. Jakarta: Republika.

Nurhayati, G. (2012). Apresiasi Prosa Fiksi. Surakarta: Cakrawala Media.

Nyoman Kutha, R. (2012). Teori Metode, dan Teknik Penelitian Sastra. Yogyakarta: Pustaka Pelajar.

Rohinah, M. N. (2011). Pendidikan Karakter Berbasis Sastra: Solusi Pendidikan Moral yang Efektif. Yogyakarta: Ar-Ruzz Media.

Samani, Muchlas., H. (2011). Pendidikan Karakter. Bandung: PT Remaja Rosdakarya.

Susanti, M. (2013). Nilai-Nilai Pendidikan Karakter Dalam Novel Nazar-Nazar Jiwa Karya Budi Sulistyo En- Nafi '. Jurnal Pendidikan Bahasa Dan Sastra Indonesia, 1(2), 274-282.

Yufarlina, Rosita. F., Achsani, F. (2018). Pendidikan Karakter Dalam Novel Cinta 2 Kodi Karya Asma Nadia. Jurnal Alayasastra. Alayasastra, 14(1).

Zubaedi. (2011). Desain Pendidikan Karakter: Konsep dan Aplikasinya Dalam Lembaga Pendidikan. Jakarta: kencana Prenada Media Group.

Zuriah, N. (2008). Pendidikan Moral dan Budi Pekerti dalam Perspektif Perubahan. Jakarta: Bumi Aksara. 
124 | Analisis Nilai-Nilai Pendidikan Karakter... 